\title{
Foraging, growth, and loss rate of young-of-the- year Atlantic salmon (Salmo salar) in relation to habitat use in Catamaran Brook, New Brunswick1
}

\author{
Isabelle L. Girard, James W.A. Grant, and Stefán Ó. Steingrímsson
}

\begin{abstract}
The ideal despotic distribution predicts that individuals occupying preferred habitats will have higher fitness than those in less preferred habitats, whereas the ideal free distribution predicts that average fitness will be equal in all habitats. To test between these two alternatives, we studied habitat use in relation to foraging, growth, and loss rates of 216 individually tagged young-of-the-year Atlantic salmon (Salmo salar). Fish were observed by snorkelling between 2 July and 4 September 1999 in Catamaran Brook, New Brunswick. In a multiple logistic regression, the variables that best discriminated between the habitats used and not used by fish were mean flow velocity and water depth; the fish preferred habitats of intermediate flow velocity $\left(6-48 \mathrm{~cm} \cdot \mathrm{s}^{-1}\right)$ and depth $(20-39 \mathrm{~cm})$. Fish in preferred habitats experienced higher levels of food abundance and had higher foraging rates but did not differ in body size or growth rate compared with those in less preferred habitats, perhaps because of higher energetic costs. In addition, loss rate did not differ significantly between preferred and less preferred habitats. Our data suggest that salmonid populations at low density may be better described by an ideal free distribution rather than by an ideal despotic one.
\end{abstract}

Résumé : La distribution idéale despotique prédit que les individus qui occupent les habitats convoités ont une meilleure fitness que ceux qui habitent les habitats moins recherchés, alors que la distribution idéale libre prédit que la fitness moyenne sera la même dans tous les habitats. Afin de choisir entre de ces deux hypothèses, nous avons étudié l'utilisation de l'habitat en fonction de la recherche de la nourriture, de la croissance et des taux de perte chez 216 jeunes saumons atlantiques (Salmo salar) de l'année marqués individuellement. La plongée en apnée nous a permis d'observer les poissons entre le 2 juillet et le 4 septembre 1999 à Catamaran Brook, Nouveau-Brunswick. Dans une régression logistique multiple, les variables qui permettent le mieux de discriminer les habitats utilisés et non utilisés par les poissons sont la vitesse moyenne du courant et la profondeur de l'eau; les poissons préfèrent des eaux de courant $\left(6-48 \mathrm{~cm} \cdot \mathrm{s}^{-1}\right)$ et de profondeur $(20-39 \mathrm{~cm})$ moyens. Par comparaison aux poissons dans les habitats moins recherchés, les poissons dans les habitats préférés ont des densités de nourriture et des taux d'alimentation plus grands, mais ils ne diffèrent pas en taille ou en taux de croissance, probablement à cause de coûts énergétiques plus élevés. De plus, les taux de perte ne varient pas entre les habitats préférés et ceux qui le sont moins. Nos données indiquent que les populations de salmonidés de faible densité peuvent être décrites plus précisément par la distribution idéale libre que la distribution idéale despotique.

[Traduit par la Rédaction]

\section{Introduction}

Habitat selection is the non-random use of space that results from the behavioural "decisions" of organisms (Kramer et al. 1997). Because this behaviour defines the realized niche of a species, it has important consequences for the fit- ness of individuals, the geographical distribution of populations, and the partitioning of resources within communities (Partridge 1978; Kramer et al. 1997).

Habitat selection has been widely studied in stream fishes, partly as a direct response to human impacts on stream ecosystems. Hence, these studies have tended to focus on physi-

Received 6 June 2003. Accepted 31 August 2004. Published on the NRC Research Press Web site at http://cjfas.nrc.ca on 18 February 2005.

$\mathrm{J} 17605$

I.L. Girard, ${ }^{2}$ J.W.A. Grant, ${ }^{3}$ and S.Ó. Steingrímsson. ${ }^{4}$ Department of Biology, Concordia University, 7141 Sherbrooke Street West, Montréal, QC H4B 1R6, Canada.

${ }^{1}$ This paper is part of the symposium on The Status of Atlantic Salmon: Populations and Habitats, which took place on 11-14

August 2003 in Québec, Quebec, as part of the 133rd annual meeting of the American Fisheries Society.

${ }^{2}$ Present address: GENIVAR, 5858, chemin de la Côte-des-Neiges, 4e étage, Montréal, QC H3S 1Z1, Canada.

${ }^{3}$ Corresponding author (e-mail: grant@vax2.concordia.ca).

${ }^{4}$ Present address: Holar University College, 551 Saudarkrokur, Iceland. 
cal attributes of habitat to predict the effect of these impacts, such as changes in stream discharge, on the quantity and quality of fish habitat (e.g., Stalnaker and Arnette 1976). Juvenile Atlantic salmon (Salmo salar) have attracted considerable attention in this literature because of their economic and cultural value (see Armstrong et al. 2003). In response to the worldwide decline in Atlantic salmon populations (Parrish et al. 1998), conservation and restoration plans now list information about optimal habitat requirements for juveniles as a priority item (Dodson et al. 1998).

Optimal habitats are typically identified as those with the highest population density (see Kramer et al. 1997). Although population density is often correlated with the intrinsic suitability of a habitat (i.e., fitness of individuals when population density approaches zero), the realized suitability of a habitat is density-dependent, because the fitness of individuals often decreases with increasing population density. The ideal free distribution, the most general model of density-dependent habitat selection, predicts that population densities will be directly proportional to habitat productivity such that individuals will have equal fitness across habitats of varying preference and density (Fretwell and Lucas 1970). Hence, no single habitat type is optimal because the best choice for an individual depends on the decisions of others (Kramer et al. 1997). In the ideal despotic distribution, however, aggressive behaviour restricts the entry of individuals into higher quality habitats such that fitness will be higher in preferred habitats with higher population density (Fretwell and Lucas 1970; Kramer et al. 1997). Whether or not fish populations conform to an ideal free distribution versus an ideal despotic distribution has potentially important management implications. In an ideal free distribution, all habitats used by fish will contain high quality individuals and produce recruits to the population, whereas in an ideal despotic distribution, habitat managers will want to focus more narrowly on protecting or augmenting the highest quality habitats occupied by the fish of highest fitness (see Kramer et al. 1997).

By comparing the habitat used with the habitat available in streams, many studies have shown that juvenile Atlantic salmon have distinct habitat "preferences". Of the commonly measured variables, the most important variables influencing habitat selections are typically flow velocity followed by water depth (e.g., deGraaf and Bain 1986; Morantz et al. 1987; Armstrong et al. 2003). Juvenile salmon initially prefer slow flow velocities and shallow water depths but gradually move into faster, deeper water as they grow (Symons and Heland 1978; Rimmer et al. 1984; Morantz et al. 1987).

Quantifying the relationship between population density, or habitat preference, and fitness is crucial for testing between the ideal free and ideal despotic distributions, both of which have been applied to stream salmonids (Pert and Erman 1994; Bult et al. 1999; Armstrong et al. 2002). Because of their conspicuous territorial behaviour (e.g., Keeley and Grant 1995) and limited mobility (e.g., Steingrímsson and Grant 2003), some authors have speculated that salmon populations would conform to an ideal despotic distribution (Kramer et al. 1997; Armstrong et al. 2002). Territorial behaviour, however, does not preclude an ideal free distribution, because territoriality need not have a density-limiting effect (sensu Fretwell and Lucas 1970). Indeed, the ideal free distribution was originally conceived to describe how territorial birds would settle in habitats of varying quality (Fretwell and Lucas 1970).

With two notable exceptions, relatively few studies have measured components of the fitness of fish occupying habitats of differing preference. First, young-of-the-year (YOY) Atlantic salmon preferred habitats that were predicted to provide a high foraging rate (Nislow et al. 1999). Moreover, preferred sites retained a higher proportion of fish over the summer. Second, in an elegant field experiment, juvenile cutthroat trout (Oncorhynchus clarki) grew faster in pools, their preferred habitat, than in riffles (Rosenfeld and Boss 2001).

The first goal of our study was to provide a multivariate description of the preferred habitat of YOY Atlantic salmon in the wild. Because of the strong correlation among habitat variables in streams, a multivariate approach is preferable (see Heggenes and Saltveit 1990; Guay et al. 2000) but has rarely been applied to YOY salmon (but see Bremset and Berg 1999). Second, we used foraging rate, growth rate, and loss rate from the study site to estimate components of the fitness of tagged fish occupying habitats of differing preference to test between the alternative predictions of the ideal free and despotic models of habitat distribution.

\section{Materials and methods}

\section{Study site and species}

We collected data in Catamaran Brook, a third-order tributary of the Little Southwest Miramichi River $\left(46^{\circ} 52^{\prime} 45^{\prime \prime} \mathrm{N}\right.$, $\left.66^{\circ} 06^{\prime} 00^{\prime \prime} \mathrm{W}\right)$ in central New Brunswick, Canada. Adult Atlantic salmon return to spawn in the river between late September and early November (Cunjak et al. 1993). YOY salmon remain in the stream for 2-3 years before emigrating to sea (Randall 1982; Cunjak et al. 1993). Total watershed area is about $50 \mathrm{~km}^{2}$, and the stream contains a wide range of habitat types: flats, shallow $(<46 \mathrm{~cm})$ and slow flowing $\left(<15 \mathrm{~cm} \cdot \mathrm{s}^{-1}\right)$; runs, deep $(>23 \mathrm{~cm})$ and fast flowing $\left(>15 \mathrm{~cm} \cdot \mathrm{s}^{-1}\right)$; riffles, shallow $(<23 \mathrm{~cm})$ and fast flowing $\left(>15 \mathrm{~cm} \cdot \mathrm{s}^{-1}\right)$; and pools, deep $(>46 \mathrm{~cm})$ and slow flowing $\left(<15 \mathrm{~cm} \cdot \mathrm{s}^{-1}\right)$ (Cunjak et al. 1993; Gibson et al. 1993). For a more detailed description of the stream and its Atlantic salmon population, see Cunjak et al. (1990, 1993).

Five study sites were chosen approximately $700 \mathrm{~m}$ upstream from the mouth of the brook based on two criteria: the combined sites included all four habitat types (i.e., flats, runs, riffles, and pools) and the sites were all located within a $120-\mathrm{m}$ reach in order to detect habitat shifts in individuals that moved between sites (see fig. 1 of Steingrímsson and Grant 2003). On average, the five sites were $16.25 \mathrm{~m}$ (range $=15-20 \mathrm{~m})$ in length and $5.88 \mathrm{~m}$ (range $=3.30$ $9.20 \mathrm{~m}$ ) in width. All sites were repeatedly sampled from 2 July to 4 September 1999 to obtain measurements of the habitat used by and available for the tagged individuals within the sites (Table 1). YOY salmon emerge from the gravel in mid-June and cease growing by mid-September (Randall 1982; Steingrímsson and Grant 1999). For the habitat-use measurements, we subdivided this growing season into early (8-23 July), middle (28 July - 7 August), and late (23-25 August) summer (Table 1). 
Table 1. Schedule of activities during the 1999 field season in Catamaran Brook, New Brunswick.

\begin{tabular}{|c|c|c|c|}
\hline Round & Dates & Activities & Sites \\
\hline \multirow[t]{4}{*}{1} & 2; 24 July & Measurement of availability of substrate and cover & $2-5 ; 1$ \\
\hline & $6-7 ; 9-14 ; 18-27$ July & Tagging and measurement of fork length & $2 ; 5 ; 1,3-5$ \\
\hline & $8 ; 15 ; 22-23$ July & Habitat-use measurements & $2 ; 5 ; 1,3,4$ \\
\hline & 23; 24 July & Drift samples; habitat-availability measurements & $1-5$ \\
\hline \multirow[t]{3}{*}{2} & 25-27 July; 4-6 Aug. & Locate tagged fish & $1-3 ; 3-5$ \\
\hline & 28 July; 6-7 Aug. & Habitat-use measurements & $1-3 ; 3-5$ \\
\hline & 8 Aug. & Drift samples & $1-5$ \\
\hline \multirow[t]{3}{*}{3} & 10-19 Aug. & Tagging and measurement of fork length & $1-5$ \\
\hline & $20 ; 21-22$ Aug. & Measurements of habitat use and habitat availability & $1-5$ \\
\hline & 22 Aug. & Drift samples & $1-5$ \\
\hline \multirow[t]{3}{*}{4} & 23-25 Aug. & Locate tagged fish; habitat-use measurements & $1-5$ \\
\hline & 26-27 Aug. & Foraging rates of 43 tagged fish & $1-5$ \\
\hline & 29 Aug. & Drift samples & $1-5$ \\
\hline \multirow[t]{3}{*}{5} & 30 Aug. - 2 Sept. & Locate tagged fish; habitat-use measurements & $1-5$ \\
\hline & 3; 4 Sept. & Habitat-availability measurements; drift samples & $1-5$ \\
\hline & 21-30 Sept. & Electrofishing of tagged fish; measurement of fork length & $1-5$ \\
\hline
\end{tabular}

\section{Habitat availability}

The habitat available for YOY salmon was assessed at each site after the habitat-use measurements in early (24 July), middle (21-22 August), and late (3 September) summer, yielding three rounds of habitat availability (Table 1). Within each site, transects were established perpendicular to the flow at $2.5-\mathrm{m}$ intervals. At $1-\mathrm{m}$ intervals along each transect, measurements of flow velocity, water column depth $( \pm 0.5 \mathrm{~cm}$, hereafter water depth), substrate size, and the degree of overhead cover were obtained. A portable meter (model 201D; Marsh-McBirney Inc., 4539 Metropolitan Ct., Frederick, MD 21704, USA) was used to measure flow velocity $\left( \pm 0.5 \mathrm{~cm} \cdot \mathrm{s}^{-1}\right)$ at the bottom $(2 \mathrm{~cm}$ above the substrate following deGraaf and Bain 1986), at the mean distance of the fish's snout above the substrate $($ mean $=3.6 \mathrm{~cm}$ ) while holding position in the water column at a particular site and time (see Habitat use below), and at $40 \%$ of the water depth (hereafter, mean flow velocity). We assessed the degree to which boulders, large woody debris, and water turbulence obscured our ability to see a fish, whether or not one was present, at a particular location. Cover was estimated visually from above the water surface and was categorized as follows: 0 , none (fish fully visible); 1 , partial (fish partly visible); 2, complete (fish not visible). Substrate size was measured only once, early in the summer (2 July), as it does not vary significantly over the season (deGraaf and Bain 1986; Morantz et al. 1987). At 1-m intervals along the transect, the dominant substrate along a $10-\mathrm{cm}$ line (i.e., $5 \mathrm{~cm}$ left and right of each 1-m mark on the measuring tape) was visually estimated and subsequently coded from 1 to 7 using a modified Wentworth scale of particle diameter $(\mathrm{mm})$, similar to the one used by deGraaf and Bain (1986): 1, plant detritus or clay $(<0.004) ; 2$, sand or silt $(0.004-2) ; 3$, gravel (2-16); 4, pebble (16-64); 5, cobble (64-250); 6, boulder (>250); 7, bedrock.

\section{Tagging individuals and measurements of length}

All visible YOY salmon in each site were marked from 6 to 27 July 1999 as part of a larger study of the patterns and correlates of mobility (see Steingrímsson and Grant 2003).
A total of 187 fish were captured with dipnets by a diver, who repeatedly snorkelled through each site. Five fish were caught at a time and placed in buckets containing stream water. Each individual was then anaesthetized in a mixture of 3-4 drops of clove oil in $800 \mathrm{~mL}$ of water (Keene et al. 1998) and tagged using a $1-\mathrm{cm}^{3}$ hypodermic syringe containing fluorescent elastomer paint (Dewey and Zigler 1996).

Individuals were marked using red, green, and orange elastomer at two out of eight possible locations on the fish, creating a distinctive tag for each individual (see Steingrímsson and Grant 2003). Immediately after tagging, the fork length $( \pm 0.025 \mathrm{~mm})$ of each individual was measured using callipers. The fish were allowed to recover in a bucket of water for 5-10 min and then were released at their original location of capture. Between 10 and 19 August 1999, 131 tagged individuals and 29 new individuals were retagged or tagged using the same procedure as above. All tagged individuals caught during an electrofishing sweep of all sites on 21-30 September 1999 were measured for fork length ( $n=115$; 95 of the original 187 fish and 20 of 29 tagged in August).

\section{Habitat use}

For each of five rounds of habitat-use measurements, tagged fish were found by repeatedly snorkelling through each of the five sites between 1000 and 1900 (90\% between 1300 and 1900), the period of day when YOY are most active (Breau 2003). Each site was sampled an average of 3.6 times per round (range $=1-7$ ) over $1-3$ days to ensure a good capture efficiency (see Steingrímsson and Grant 2003). Assuming that $50 \%$ of YOY salmon are hiding at any particular time during the day in summer (Breau 2003), on average we should detect $92 \%$ of the fish (i.e., $1-0.5^{3.6}$ ). Once a fish was identified, the location where it was first observed that day was marked with a numbered flag embedded in the substrate. The $x-y$ location $( \pm 5 \mathrm{~cm})$ of each fish was measured from transects established across each site at $2.5-\mathrm{m}$ intervals. Maps of the $x-y$ data were then created using ArcView GIS 3.2 software (see Steingrímsson and Grant 2003). The distance of the fish's snout above the substrate 
while holding position in the water column was estimated visually.

Once all visible individuals were located, flow velocity (bottom, snout, and mean), water depth, and cover were measured for each numbered flag using the same method described for habitat availability (see above). Substrate size was estimated visually in a $100-\mathrm{cm}^{2}$ quadrat around each flag and coded using the same method as above. Sampling all sites took between 5 and 14 days and yielded five rounds of habitat-use measurements for each site (Table 1).

\section{Food abundance}

After each of the five rounds of habitat measurements, a drift sample was taken to assess the food available in each site between 1300 and 1830. Benthic samples were not taken as a previous study indicated that most foraging attempts are directed at drifting invertebrates present in the water column and less than $1 \%$ of all foraging attempts are directed towards the benthos or the surface of the water column (Keeley and Grant 1995). A 1-m-long drift net with a metalframe opening of $15.2 \mathrm{~cm} \times 23 \mathrm{~cm}$ and a $300-\mu \mathrm{m}$ mesh size was used to obtain 25 drift samples (i.e., 5 rounds $\times 5$ sites). For each of these five sampling rounds, the drift nets were alternated between a slow-flow station (mean $=4.4 \mathrm{~cm} \cdot \mathrm{s}^{-1}$, range $=3-9 \mathrm{~cm} \cdot \mathrm{s}^{-1}$ ) and a fast-flow station (mean = $22.2 \mathrm{~cm} \cdot \mathrm{s}^{-1}$, range $=6-59 \mathrm{~cm} \cdot \mathrm{s}^{-1}$ ) within each site. To obtain an adequate sample, the drift nets were left longer in slowflow areas $($ mean $=99$ min) than in fast-flow areas $($ mean $=$ $61.5 \mathrm{~min}$ ). Immediately after setting each drift net, the following measurements were taken directly in front of the drift net using the methods described for habitat availability: bottom, snout (i.e., $3.6 \mathrm{~cm}$ above the substrate), and mean flow velocity, flow velocity at one-half of drift net height (i.e., $12 \mathrm{~cm}$ ), water temperature, and water depth. Time of day was recorded at the beginning and end of each drift sample.

All drift samples were preserved in $10 \%$ buffered formalin. We processed each sample by removing inedible material such as insect exuviae and plant material. Food items that were considered too big for YOY salmon to eat (Keeley and Grant 1997) were removed from the sample before counting the number of food items. The drift rate at each station and date was expressed as the number of edible organisms captured in a drift net per $20 \mathrm{~min}$. When water depth was less than the depth of the net $(23 \mathrm{~cm})$, this rate was prorated to the area of the drift net opening $(15.2 \mathrm{~cm} \times$ $23 \mathrm{~cm}=349.6 \mathrm{~cm}^{2}$ ).

\section{Foraging rate}

To minimize environmental variability while quantifying foraging rate, we concentrated our effort during 2 days (2627 August 1999) during which no extreme weather events occurred (i.e., rainfall or water temperature). The foraging rate of 43 individuals was measured between 1500 and 1930 and water temperatures between 21.5 and $23.0{ }^{\circ} \mathrm{C}$, the conditions under which YOY salmon are most active (Nislow et al. 1999; Breau 2003). Water clarity was also excellent for observing fish because no major rain event occurred in the previous week. Once a tagged individual was located via snorkelling, the tag of the fish was noted and the fish was allowed to acclimate to the observer's presence (i.e., $>1 \mathrm{~m}$ downstream of the fish) for 5 min before any measurements were taken (Heggenes and Saltveit 1990). Each individual was then observed for $10 \mathrm{~min}$ to count the number of foraging attempts, i.e., rapid movements towards a potential food item.

\section{Statistical analysis}

To meet the assumptions of parametric tests, flow velocity, water depth, drift rate, and foraging rate were $\log _{10^{-}}$ transformed before analyses. In a few areas of the stream, the flow velocity meter did not detect any flow (i.e., $0.0 \mathrm{~cm} \cdot \mathrm{s}^{-1}$ ); these were scored as $0.5 \mathrm{~cm} \cdot \mathrm{s}^{-1}$ to facilitate the $\log _{10}$ transformation. However, for ease of interpretation, we report the medians or back-transformed means and estimates of variability. When the transformed data did not meet the assumptions of parametric tests, we used non-parametric tests.

Habitat preference was assessed by plotting frequency distributions of the habitat used by salmon versus the habitat available in the stream. Goodness-of-fit tests (i.e., $G$ tests; Sokal and Rohlf 1995) were used to test for overall differences between the distributions of use and availability for each variable. Single degrees of freedom (df) $\chi^{2}$ tests were used to identify significant differences between use and availability for each category of the variable. Habitat preference or avoidance was defined as the use of a habitat category significantly more or less often, respectively, than one would expect based on its availability in the stream.

To use a multiple logistic regression, we transformed our habitat-availability datasets into habitat-not-used datasets by removing all locations that were within the territories of fish. In each of the three sampling periods, all fish in the habitatuse dataset were mapped using ArcView GIS 3.2 software (see Steingrímsson and Grant 2003). For each of these sampling periods, we used Keeley and Grant (1995) to estimate the average territory radius $(0.26,0.35$, and $0.40 \mathrm{~m}$, respectively) based on the average fork length of fish (4.47, 5.22, and $5.64 \mathrm{~cm}$, respectively). Any habitat-availability locations that were within these territories were deleted. For each fish in the habitat-use dataset, we then randomly selected one not-used location. We used multiple logistic regressions to determine the key variables that distinguished between used and not-used habitat in early, middle, and late summer (see Guay et al. 2000). The probability of YOY salmon using a habitat was then used as a multivariate measure of habitat preference, which was calculated for the location of each fish and each grid location for each of the early, middle, and late summer samples. We calculated the density of fish in preferred and not-preferred habitats (probability of use $>0.50$ or $<0.50$, respectively) by counting the number of fish and the amount of habitat in each category in each sample.

Fork length of the tagged fish (range $=33.1-63.0 \mathrm{~mm}$ ) increased linearly over the season until it levelled off sharply towards the end of the summer (Girard 2002). We assumed that growth rate had ceased by the time fish were electrofished (i.e., day of year $=264-273$ ). A date for the cessation of growth was estimated as the intersection between a linear regression of fork length on date before electrofishing (i.e., day of year < 241) and the mean fork length of fish caught during electrofishing (i.e., fork length = $57.1 \mathrm{~mm})$. The intersection point was on 5 September. 
Hence, we assumed that growth rate was linear over the season and ceased on 5 September (Girard 2002).

Individual growth rate was calculated as (final - initial fork length) $\times$ (final - initial day of year of the fork length measurement $)^{-1}$. Because fork length was measured in three separate rounds (Table 1), two measures of growth rate were calculated: early summer (i.e., between rounds 1 and 3) and late summer (i.e., between round 3 and electrofishing).

\section{Results}

Of the 216 YOY salmon tagged, $86.6 \%$ were relocated sometime throughout the summer. In general, the tagged fish were extremely sedentary, with $96.4 \%$ of recaptured fish moving less than $5 \mathrm{~m}$ either up- or down-stream from their original tagging location. For a detailed analysis of the movement of these fish, see Steingrímsson and Grant (2003).

\section{Univariate analysis of habitat preference}

The three measures of flow velocity (i.e., bottom, snout, and mean) were highly intercorrelated, both for the habitat used by fish (Pearson's correlation, $r$ values $>0.58, n=737$, $P$ values $<0.001)$ and available in the stream $(r$ values $>$ $0.81, n=603, P$ values $<0.001)$. Also, a multiple logistic regression analysis (see below) showed that the mean flow velocity was the most important of the three in distinguishing between habitat used and not used by YOY salmon. Consequently, we present data only for mean flow velocity, hereafter called flow velocity.

Flow velocity $\left(\mathrm{cm} \cdot \mathrm{s}^{-1}\right)$ available in the stream changed significantly over the summer (repeated-measures analysis of variance, ANOVA, $\left.F_{[2,376]}=66.3, P<0.001\right)$, increasing from early in the summer to mid-summer and then decreasing in late summer (Fig. 1). Flow velocity used by YOY salmon also changed significantly over the five sampling rounds $\left(\right.$ ANOVA, $F_{[4,264]}=11.4, P<0.001$ ), in parallel with changes in flow velocity available. Flow velocity used increased from a median of 7.0 in early summer to 12.0 in mid-summer and then decreased to 6.0 in late summer. YOY generally avoided slow flows $\left(<3 \mathrm{~cm} \cdot \mathrm{s}^{-1}\right)$ and preferred moderate flows $\left(>6 \mathrm{~cm} \cdot \mathrm{s}^{-1}\right.$ ) (Fig. 1). The distribution of flow velocities used by fish differed significantly from those available in early, middle, and late summer (early, $G=$ 112.6, df $=5, P<0.001$; middle, $G=110.4$, df $=5, P<$ 0.001 ; late, $G=105.4$, df $=5, P<0.001$ ). Early (Fig. 1a) and late (Fig. 1c) in the summer, fish significantly preferred flow velocities between 6 and $24 \mathrm{~cm} \cdot \mathrm{s}^{-1}$ and significantly avoided flow velocities below $1.5 \mathrm{~cm} \cdot \mathrm{s}^{-1}\left(\chi^{2}\right.$ tests, $\mathrm{df}=1$, $P$ values $<0.005$ ). In mid-summer (Fig. $1 b)$, however, YOY significantly preferred flow velocities between 12 and $48 \mathrm{~cm} \cdot \mathrm{s}^{-1}$ and significantly avoided flow velocities below $3 \mathrm{~cm} \cdot \mathrm{s}^{-1}$. YOY salmon were always found less often than expected in flow velocities greater than $48 \mathrm{~cm} \cdot \mathrm{s}^{-1}$. These seasonal trends in apparent habitat preference followed seasonal trends in flow velocity in the stream.

Water depth available in the stream changed significantly (ANOVA, $\left.F_{[2,376]}=49.9, P<0.001\right)$ over late summer and showed the same seasonal patterns as flow velocity (Fig. 2). Water depth used by fish in the stream also changed significantly over the five sampling rounds (ANOVA, $F_{[4,264]}=$
Fig. 1. Frequency distribution of the mean flow velocity of the water column available to (solid bars) and used by (hatched bars) young-of-the-year Atlantic salmon (Salmo salar) in (a) early (2-28 July; $n=200$ and 187 for availability and use, respectively), (b) middle (10-22 Aug.; $n=211$ and 160 for availability and use, respectively), and (c) late summer (30 Aug. 3 Sept.; $n=192$ and 128 for availability and use, respectively) of 1999. Asterisks indicate categories where single-df $\chi^{2}$ tests yielded significant differences between use and availability. Horizontal lines show the grouping of categories for the $\chi^{2}$ tests.

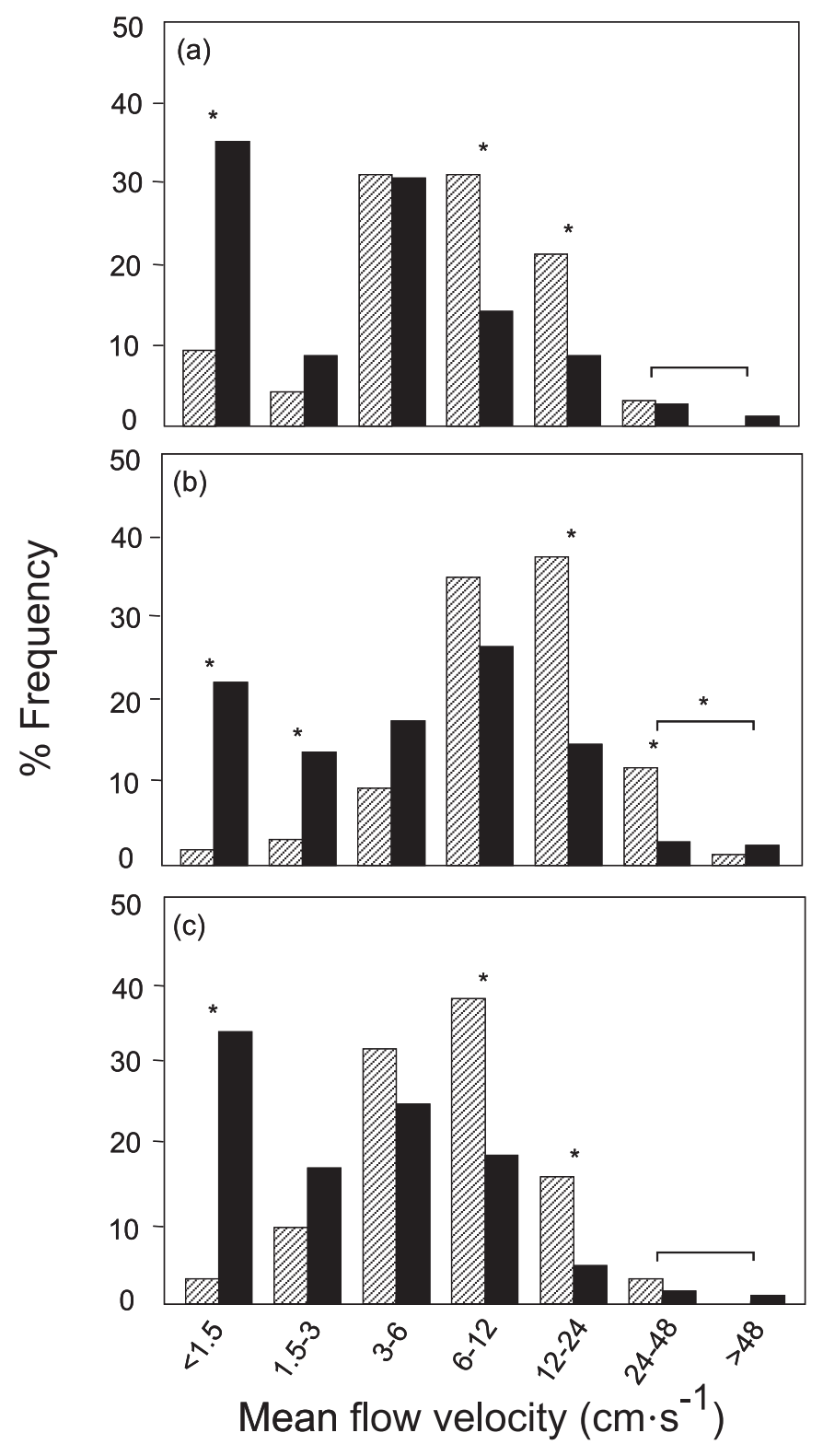

4.91, $P<0.001$ ), increasing from early summer to midsummer and then decreasing in late summer (Fig. 2). The distribution of water depths used by fish differed significantly from that available in all three time periods (early, $G=101.2, \mathrm{df}=7, P<0.001 ;$ middle, $G=173.6$, df $=7, P<$ 0.001 ; late, $G=133.5$, df $=7, P<0.001$ ) (Fig. 2). Early (Fig. 2a) and late (Fig. 2c) in the summer, YOY salmon significantly preferred water depths between 20 and $39 \mathrm{~cm}$ and 
Fig. 2. Frequency distribution of the water depths available to (solid bars) and used by (hatched bars) young-of-the-year Atlantic salmon (Salmo salar) in (a) early (2-28 July; $n=200$ and 187 for availability and use, respectively), (b) middle (10-22 Aug.; $n=211$ and 160 for availability and use, respectively), and (c) late summer (30 Aug. - 3 Sept.; $n=192$ and 128 for availability and use, respectively) of 1999. Asterisks indicate categories where single-df $\chi^{2}$ tests yielded significant differences between use and availability. Horizontal lines show the grouping of categories for the $\chi^{2}$ tests.
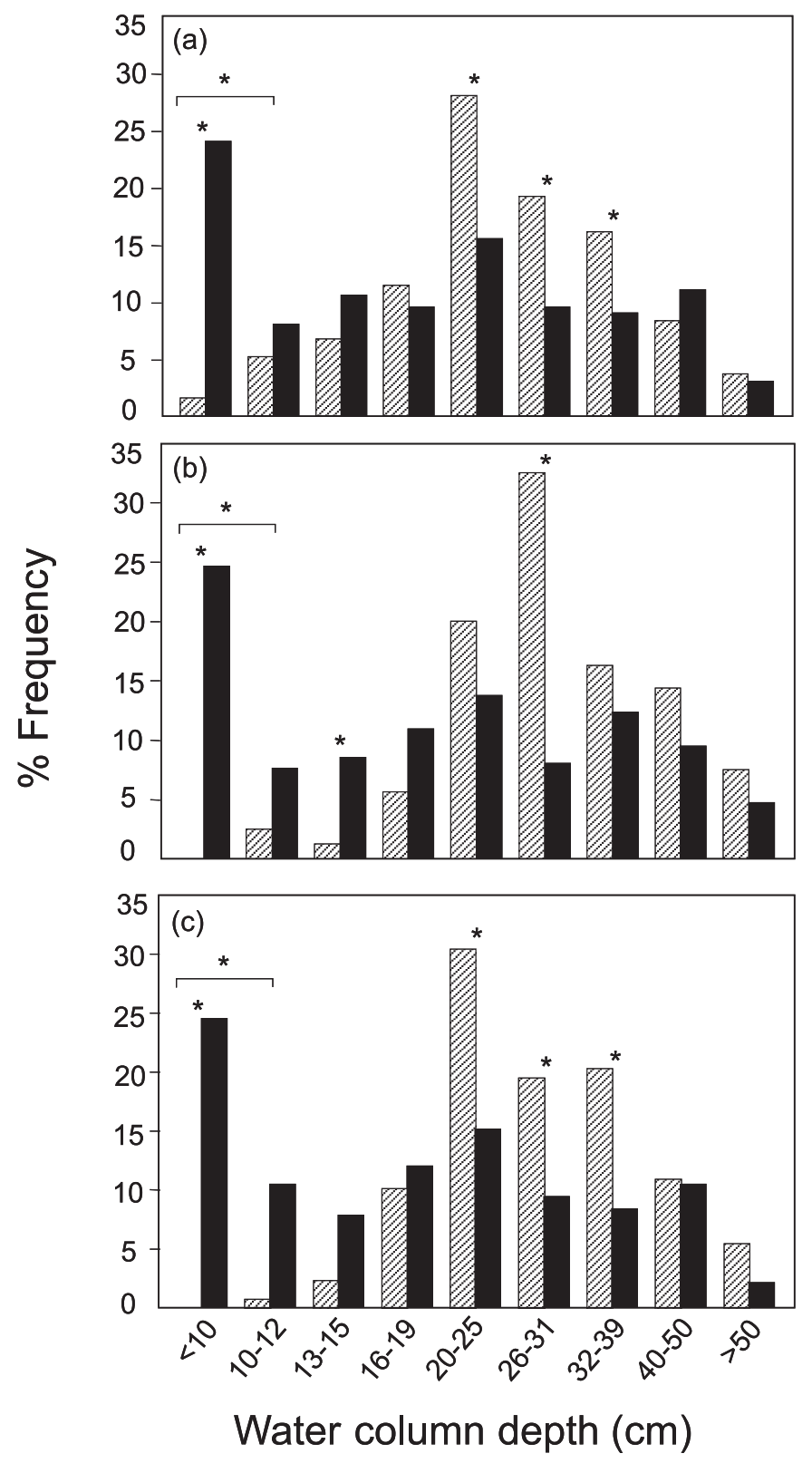

avoided water depths below $12 \mathrm{~cm}\left(\chi^{2}\right.$ tests, $\mathrm{df}=1, P$ values $<0.005$ ). In mid-summer (Fig. $2 b$ ), water depths between 26 and $1 \mathrm{~cm}$ were significantly preferred, whereas water depths below $15 \mathrm{~cm}$ were significantly avoided.

The dominant substrate types available in the stream were pebble and cobble (Fig. 3a). The average substrate size used by fish did not change significantly over the summer (median $=4.6,4.6$, and 4.7 in early, mid-, and late summer, re-
Fig. 3. Frequency distribution of (a) substrate sizes (1, plant detritus and particles $<0.004 \mathrm{~mm} ; 2$, sand or silt; 3 , gravel; 4 , pebble; 5 , cobble; 6 , boulder) and $(b)$ degree of overhead cover ( 0 , no cover; 1 , partial cover; 2 , complete cover) available to ( solid bars; $n=205$ ) and used by (hatched bars; $n=475$ ) young-of-the-year Atlantic salmon (Salmo salar) in Catamaran Brook in the summer of 1999. Asterisks indicate categories where single-df $\chi^{2}$ tests yielded significant differences between use and availability. Horizontal lines show the grouping of categories for the $\chi^{2}$ tests.
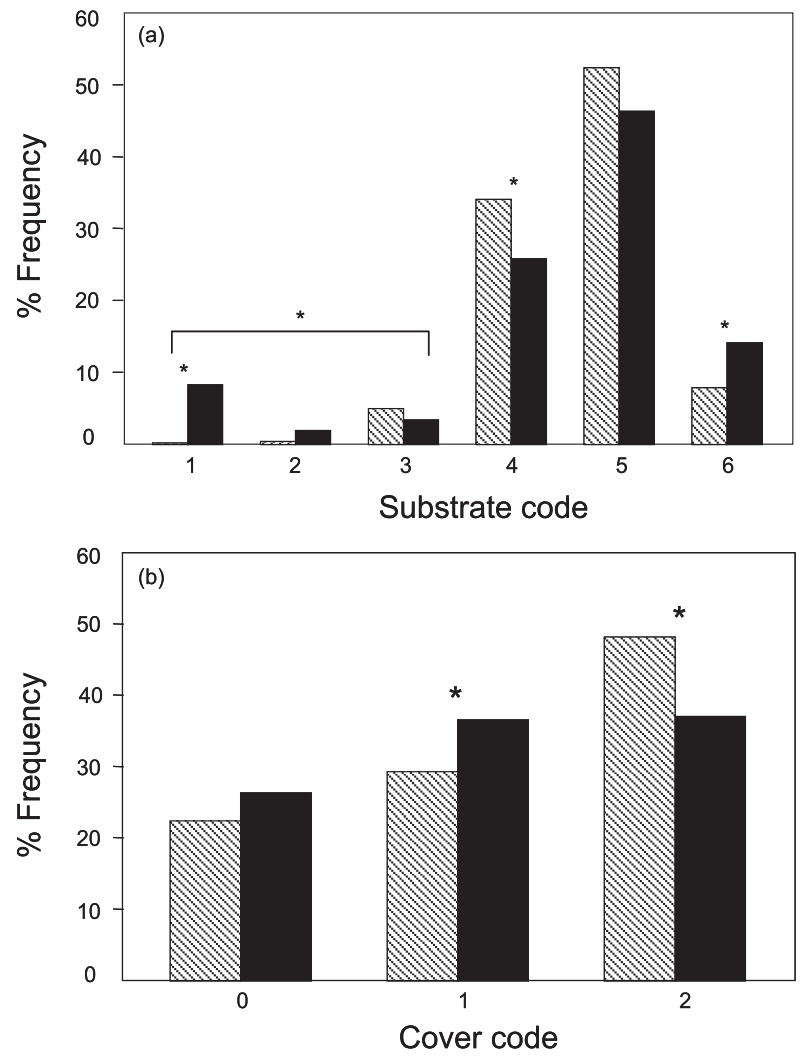

spectively; ANOVA, $\left.F_{[4,264]}=1.41, P=0.23\right)$. Because the availability of substrate and cover was measured only once during the summer, habitat use was combined for all three time periods and then compared with availability. The distribution of substrate used by fish differed significantly from that available in the summer of 1999 ( $G=60.3$, df $=3, P<$ $0.001)$; fish significantly preferred a pebble substrate and significantly avoided boulders and substrates smaller than pebbles $\left(\chi^{2}\right.$ tests, df $=1, P$ values $\left.<0.01\right)$ (Fig. $\left.3 a\right)$.

The use of cover by fish changed significantly over the summer $(G=14.5$, df $=4, P<0.01$, not shown $)$, but fish predominantly used complete cover $(47 \%, 42 \%$, and $59 \%$ in the early, mid-, and late summer, respectively). The distribution of cover types used by fish differed significantly from that available in the stream $(G=25.1$, df $=2, P<0.001)$. YOY salmon significantly preferred complete cover and significantly avoided areas with partial cover $\left(\chi^{2}\right.$ tests, df $=1$, $P$ values $<0.01)($ Fig. $3 b)$.

\section{Multivariate analysis of habitat preference}

A forward stepwise multiple logistic regression was used to identify the key habitat variables that best differentiated between the habitat used and not used by salmon. A separate 
Fig. 4. Multiple logistic regression models relating the probability of young-of-the-year (YOY) Atlantic salmon (Salmo salar) using a habitat in relation to flow velocity and water depth in (a) early (2-28 July), (b) middle (10-22 Aug.), and (c) late summer (30 Aug. - 3 Sept.) of 1999. The probability of YOY using a habitat was best described as follows: early, $\log _{\mathrm{e}}(p / 1-p)=$ $1.35 \log _{10}$ flow velocity $\left(\mathrm{m} \cdot \mathrm{s}^{-1}\right)+18.55 \log _{10}$ water depth $(\mathrm{cm})-$ $6.39 \log _{10}$ water depth ${ }^{2}\left(\mathrm{~cm}^{2}\right)-11.13\left(X^{2}=90.69, n=372\right.$, df $=$ $3, P<0.001)$; mid-summer, $\log _{\mathrm{e}}(p / 1-p)=2.01 \log _{10}$ flow velocity $\left(\mathrm{m} \cdot \mathrm{s}^{-1}\right)+32.15 \log _{10}$ water depth $(\mathrm{cm})-10.40 \log _{10}$ water $\operatorname{depth}^{2}\left(\mathrm{~cm}^{2}\right)-21.90\left(X^{2}=121.96, n=320\right.$, df $\left.=3, P<0.001\right)$; and late summer, $\log _{\mathrm{e}}(p / 1-p)=2.27 \log _{10}$ flow velocity $\left(\mathrm{m} \cdot \mathrm{s}^{-1}\right)$ $+40.40 \log _{10}$ water depth $(\mathrm{cm})-13.08 \log _{10}$ water depth ${ }^{2}\left(\mathrm{~cm}^{2}\right)-$ $27.11\left(X^{2}=116.69, n=256\right.$, df $\left.=3, P<0.001\right)$.

logistic regression was performed on each time period to explore differences over time. In addition, the statistical significance of all variables raised to a power of 2, as well as all interaction terms, was assessed. Only two key variables contributed significantly to the model for each time period: flow velocity and water depth (logistic regression, early, $X^{2}=$ 90.69, df $=3, P<0.001,67.7 \%$ correct classification (Fig. 4a); middle, $X^{2}=121.96$, df $=3, P<0.001,75.9 \%$ correct classification (Fig. $4 b$ ); late summer, $X^{2}=116.69$, df $=3, P<0.001,77.0 \%$ correct classification (Fig. 4c)). Habitat preference of YOY salmon was consistent throughout the summer; probability of YOY using a habitat increased with flow velocity and increased with water depth until about $30 \mathrm{~cm}$ and then decreased (Fig. 4).

The probability of YOY salmon using a habitat was then used as a multivariate measure of habitat preference, which can be assigned to the location of each fish and each grid location in each of the early-, mid-, and late-summer samples. We calculated the density of fish in the preferred and notpreferred habitats, respectively (i.e., probability-of-use scores $>0.5$ or $<0.5$, respectively) by counting the number of fish and the amount of habitat in both habitat categories in each of the three samples. The mean density of fish was 8.0 times higher in the preferred $\left(\right.$ mean $=0.72 \mathrm{~m}^{-2}$, range $=$ $0.69-0.78, n=3$ ) than in the not-preferred (mean $=0.09$ $\mathrm{m}^{-2}$, range $=0.06-0.14, n=3$ ) habitats.

\section{Food abundance}

The number of organisms captured in a 20-min drift-net sample $($ mean $=5.7$, mean - standard deviation $(\mathrm{SD})=1.35$, mean $+\mathrm{SD}=23.93$ ) increased with flow velocity (partial correlation, $r=0.93, n=25, P<0.001$ ) and decreased with water depth (partial $r=-0.45, n=25, P<0.05$ ) and day of year (partial $r=-0.60, n=25, P<0.005$ ). When all three variables were included in a multiple regression, drift rate was best predicted by $\log _{10}$ (number of organisms per $20 \mathrm{~min})=1.38$ ( \pm standard error 0.093$) \log _{10}$ flow velocity $\left(\mathrm{m} \cdot \mathrm{s}^{-1}\right)-0.0083( \pm 0.0020)$ day of year $-0.94( \pm 0.401)$ $\log _{10}$ water depth $(\mathrm{cm})+5.48( \pm 0.819)\left(r^{2}=0.96, n=25\right.$, $P<0.001)$. This model was used to predict the number of organisms flowing through the width of a drift net $(15.2 \mathrm{~cm})$ for the location of each fish over the summer. The predicted drift rate was prorated to the height of the water column experienced by each fish in each time period. This measure of (a)

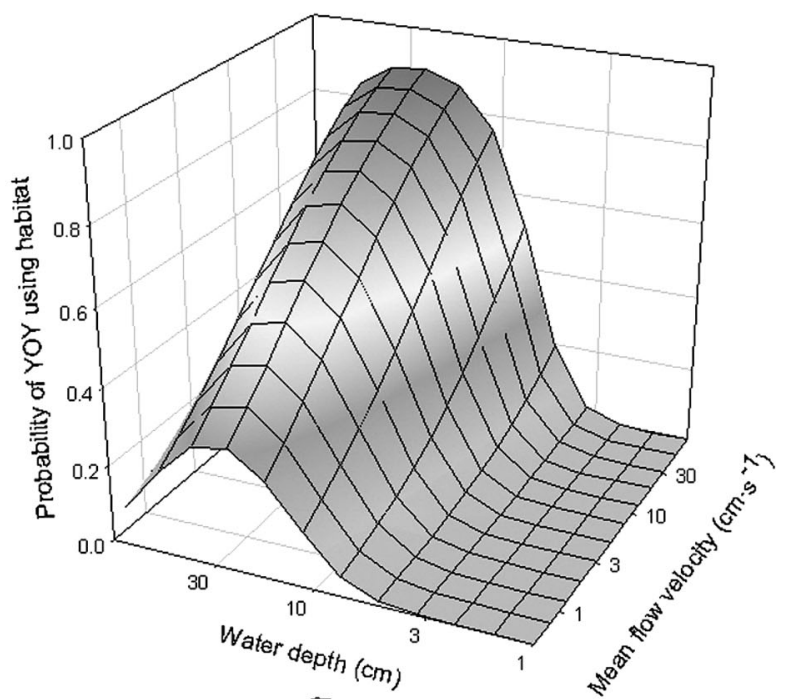

(b)

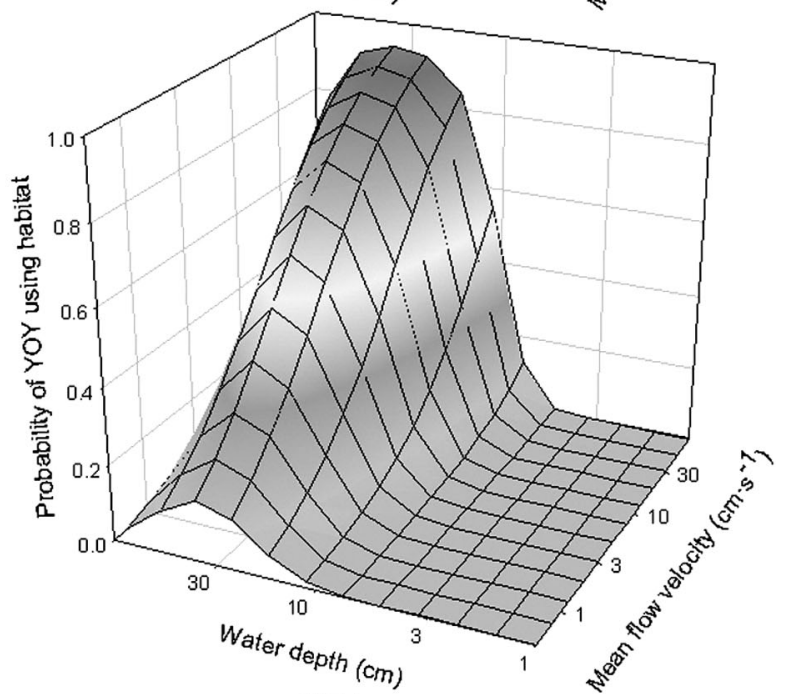

(c)

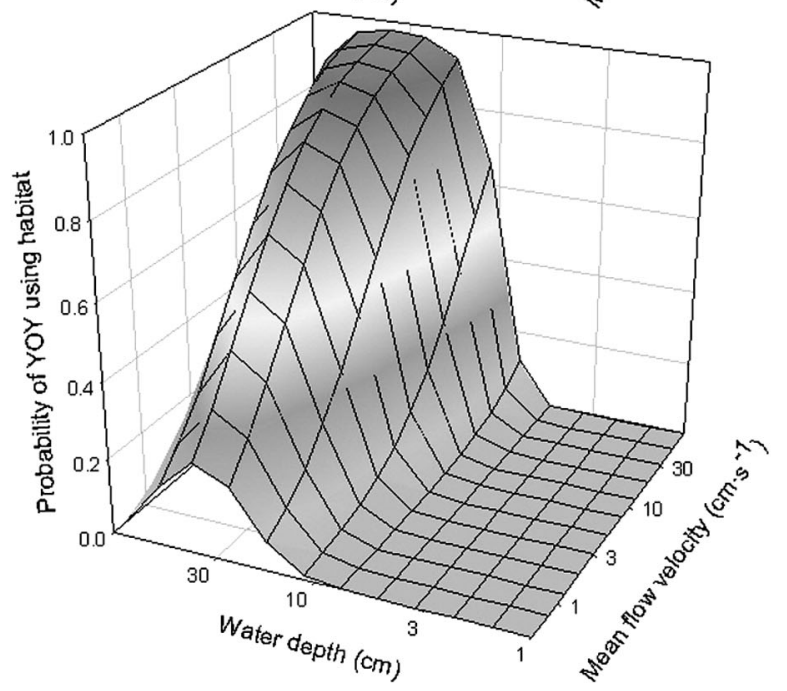

food availability was then compared with the multivariate habitat preference for fish in early, middle, and late summer.

Over the summer, the predicted drift rate always increased with the probability of YOY using a habitat (Pearson's correlation: early, $r=0.82, n=186, P<0.001$; middle, $r=$ 
Fig. 5. Relationship between the foraging rate of 43 young-ofthe-year (YOY) Atlantic salmon (Salmo salar) in late summer (26-27 Aug.) of 1999 and (a) mean flow velocity $\left(\mathrm{m} \cdot \mathrm{s}^{-1}\right)$ and degree of overhead cover (no cover, and broken line, $\log _{10}$ foraging rate $=0.302 \log _{10}$ flow velocity +0.64 ; partial cover, $\square$ and solid line, $\log _{10}$ foraging rate $=0.302 \log _{10}$ flow velocity +0.84 ; complete cover, $\boldsymbol{\Delta}$ and dotted line, $\log _{10}$ foraging rate $=0.302 \log _{10}$ flow velocity +0.76$)$ and $(b)$ the probability of YOY using a habitat (average probability between middle and late summer).
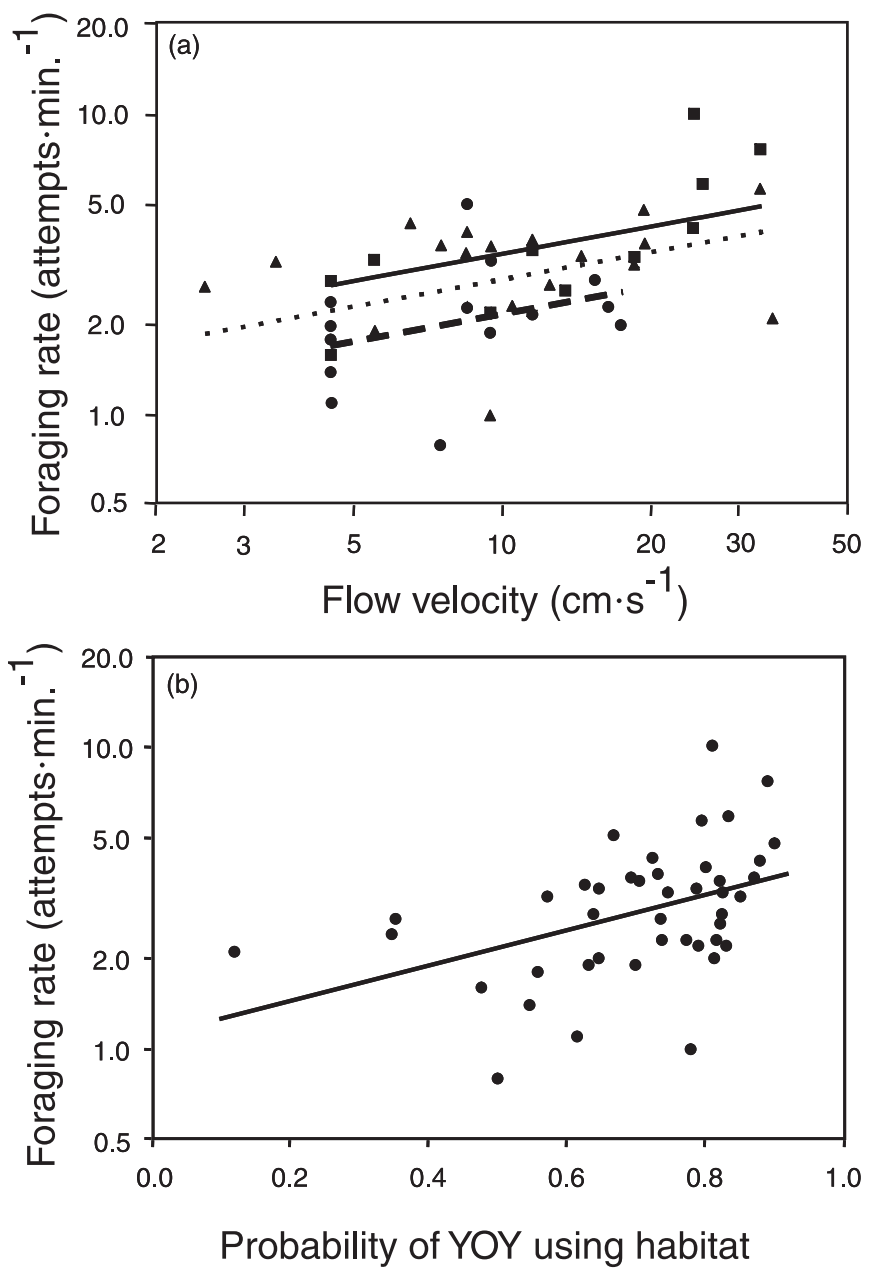

0.85, $n=155, P<0.001$; late summer, $r=0.76, n=126$, $P<0.001)$. These strong relationships were not surprising because both drift rate and habitat preference were positively related to flow velocity.

\section{Correlates of fitness}

Foraging rate of fish $\left(\right.$ mean $=2.84$ attempts $\cdot \mathrm{min}^{-1}$, mean $\mathrm{SD}=1.71$, mean $+\mathrm{SD}=4.72$ ) increased with flow velocity (analysis of covariance, ANCOVA, $F_{[1,39]}=8.93, P<0.005$ ) and was highest when fish experienced partial cover $\left(\right.$ ANCOVA, $F_{[2,39]}=4.00, P<0.05$ (Fig. $\left.5 a\right)$ ). Flow velocity and cover combined explained $37.4 \%$ of the variation in foraging rate. Foraging rate was not correlated with any other habitat variable (partial $r$ values $<0.28, n=43, P$ values $>$ $0.05)$. Foraging rate increased with the probability of YOY using a habitat ( $r=0.43, n=43, P<0.004$; Fig. 5b).
Fig. 6. Relationship between residual growth rate and a multivariate measure of habitat preference for $(a) 132$ young-ofthe-year (YOY) Atlantic salmon (Salmo salar) in early summer (July 6 - 19 Aug.) and (b) 81 YOY salmon in late summer (10 Aug. - 30 Sept.) of 1999. Early growth rate was compared with the average of the probability-of-use scores from early and mid-summer, whereas late growth rate was compared with the probability-of-use scores for mid- and late summer.

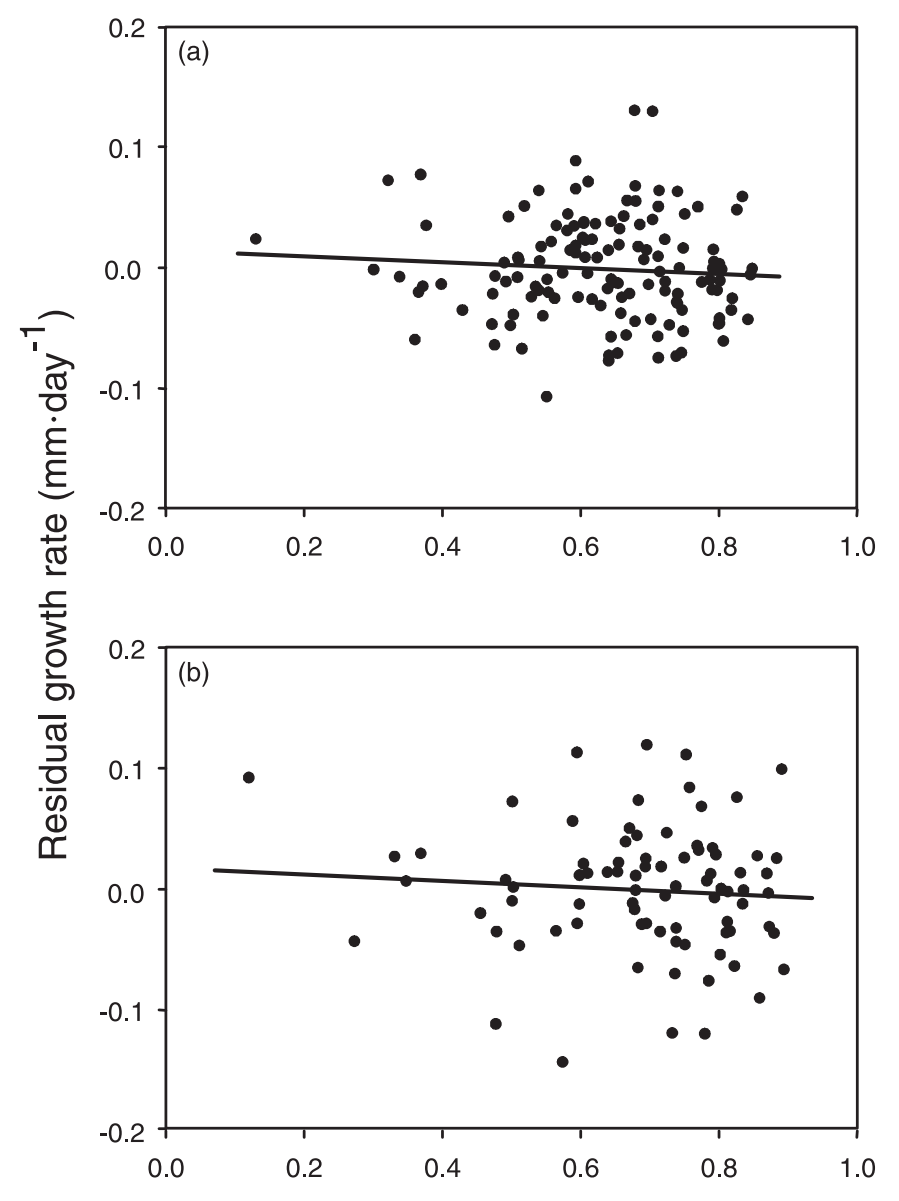

Probability of YOY using habitat

Growth rate decreased with increasing initial body size for each of the two periods in which growth was assessed (Girard 2002). To control for the effect of initial fork length on growth rate, the residuals from a quadratic relationship $\left(\right.$ early growth rate $\left(\mathrm{mm} \cdot \mathrm{day}^{-1}\right)=1.880-0.0659$ fork length $(\mathrm{mm})+0.000640$ fork length ${ }^{2}(\mathrm{~mm}), r^{2}=0.330, n=137$, $P<0.001$; late growth rate $\left(\mathrm{mm} \cdot \mathrm{day}^{-1}\right)=4.050-0.139$ fork length $(\mathrm{mm})+0.00126$ fork length ${ }^{2}(\mathrm{~mm}), r^{2}=0.404, n=$ 107, $P<0.001$; see Girard 2002 and fig. 6 of Steingrímsson and Grant 2003) were used as an estimate of early and late growth rate in further analyses. Fish that grew relatively quickly for their length in early summer also tended to grow relatively quickly late in the summer (Pearson's $r=0.26, n=$ $86, P<0.05)$. However, because the correlation was relatively weak, growth rate was analysed separately for early and late summer.

Growth rate in early and late summer was not correlated with the probability of YOY using a habitat (Pearson's $r$, early, $r=-0.06, n=132, P=0.49$; late, $r=-0.08, n=81$, 
$P=0.50$ (Fig. 6)). Foraging rate was negatively correlated with late summer growth $(r=-0.48, n=28, P<0.01$; not shown).

To test whether larger fish were found in habitats of higher preference, we compared the size of fish in rounds 1 and 3 and captured via electrofishing with their probability-of-use scores in early, middle, and late summer, respectively. Body size was not significantly related to habitat preference in early (Spearman's $r=-0.063, n=187, P=0.20$ ), middle (Spearman's $r=0.097, n=157, P=0.11$ ), or late (Spearman's $r=-0.128, n=87, P=0.12$ ) summer.

To test whether loss rate (i.e., mortality and emigration) was related to habitat preference, we noted whether or not the 187 fish tagged in round 1 were captured in the electrofishing survey in late September. Of the 187 fish, 95 were recaptured in the study site at the end of the summer. Whether or not fish were recaptured was not related to their initial habitat preference score in round 1 (logistic regression, $X^{2}=0.03$, df $=1, P=0.86$ ). The percentage lost from the study site was $49 \%$ for both preferred (73/148) and notpreferred (19/39) habitats.

\section{Discussion}

In the univariate analyses, YOY salmon in Catamaran Brook exhibited distinct habitat preferences for flow velocity, water depth, substrate size, and degree of overhead cover, as documented in many earlier studies (for a review, see Armstrong et al. 2003). In the multiple logistic regressions, however, only flow velocity and water depth significantly discriminated between the habitat used and not used in the stream. Because of the strong correlation among habitat variables in streams, either an experimental approach (Holm et al. 2001) or a multivariate analysis of habitat selection in the wild (see Heggenes and Saltveit 1990; Bremset and Berg 1999; Guay et al. 2000) is required to identify crucial habitat variables for stream fishes.

YOY salmon in our study preferred flow velocities of 6$48 \mathrm{~cm} \cdot \mathrm{s}^{-1}$ and water depths of $20-39 \mathrm{~cm}$. These results are similar to the preferred flow velocities and depths observed in previous studies of YOY Atlantic salmon: $5-50 \mathrm{~cm} \cdot \mathrm{s}^{-1}$ and 15-50 cm (deGraaf and Bain 1986); 10-40 $\mathrm{cm} \cdot \mathrm{s}^{-1}$ and 20-40 cm (Morantz et al. 1987); 20-60 $\mathrm{cm} \cdot \mathrm{s}^{-1}$ and 15$20 \mathrm{~cm}$ (Scruton and Gibson 1993); 8-18 cm.s ${ }^{-1}$ and 10$20 \mathrm{~cm}$ (Nislow et al. 1999); and 15-20 cm.s ${ }^{-1}$ (Holm et al. 2001).

Like other studies, flow velocity was the single best variable in our study that discriminated habitat used and not used by fish (deGraaf and Bain 1986; Morantz et al. 1987), presumably because the drift rate of invertebrates increased with increasing flow velocity. Because the energetic costs of capturing prey also increase with increasing flow velocity, whereas prey capture success decreases, a trade-off exists between the benefits and costs of foraging in habitats of varying flow velocity (Hill and Grossman 1993; Nislow et al. 1999). Hence, foraging sites in intermediate flow velocities may be preferred (Nislow et al. 1999) or defended most vigorously (Grant and Noakes 1988).

In our study, YOY Atlantic salmon avoided shallow-water habitats and preferred habitats of intermediate depth, as observed previously in Catamaran Brook (Steingrímsson and
Grant 1999) and in other populations (deGraaf and Bain 1986; Morantz et al. 1987). Salmonid fish may avoid shallow water because it restricts the cross-sectional area of stream that can be scanned for food (Hughes and Dill 1990). In addition, they may be more vulnerable to predators in shallow water (Rosenfeld and Boss 2001). YOY salmonids may also avoid or be excluded from deeper water because of competition with larger fish, which occupy deeper and faster water in Catamaran Brook (Keeley and Grant 1995).

Habitat preferences in our study were affected by small temporal changes in habitat availability; the apparent preference for flow velocity paralleled changes in overall flow velocity in the stream. Most YOY salmon were extremely sedentary (Steingrímsson and Grant 2003) and likely tolerate small changes in environmental conditions rather than relocate their home range. This effect was clearly demonstrated in a laboratory experiment where median flow velocity used by YOY salmon increased from 7 to $24 \mathrm{~cm} \cdot \mathrm{s}^{-1}$ when discharge was increased from 2.6 to $46.8 \mathrm{~L} \cdot \mathrm{s}^{-1}$ (Holm et al. 2001).

Fish in preferred habitats experienced higher absolute levels of drift and had higher foraging rates but did not differ in body size or growth rate. Growth rate of juvenile salmon is an important component of fitness, because faster-growing fish smolt at a younger age (Hutchings and Jones 1998). However, juvenile salmon trade off the benefits of fast growth for high survival (e.g., Metcalfe et al. 1999), so it was not necessarily surprising that growth rate was not related to habitat preference. However, our loss rate data, which includes mortality rate, suggest that mortality rate also did not vary with habitat preference. Steingrímsson and Grant (2003) estimated that $66 \%$ of the loss of fish was due to mortality, based on long-term demographic data. Taken together, these results are more consistent with an ideal free distribution rather than an ideal despotic distribution. The intrinsic benefits of the preferred sites (i.e., higher food availability) were apparently offset by higher population densities and perhaps the higher foraging costs in the faster water (Hill and Grossman 1993; Nislow et al. 1999).

Given the low average density of YOY salmon observed in our study $\left(\right.$ mean $=0.58 \mathrm{~m} \cdot \mathrm{s}^{-2}$, range $=0.08-1.19$; Steingrímsson and Grant 2003) and the small size of their territories (Keeley and Grant 1995), we might have expected all fish to settle in the preferred habitats without suffering density-dependent effects. However, the negative effects of density on the growth rate of YOY Atlantic salmon in Catamaran Brook can be detected at densities as low as 0.1 fish $\cdot \mathrm{m}^{-2}$ (Imre 2003), densities much lower than one would expect the occurrence of space limitation (sensu Grant and Kramer 1990). Presumably, the density-dependent growth at such low densities occurs primarily via exploitative rather than interference competition (Imre 2003; also see Walters and Juanes 1993). Interestingly, in 1995, the density of YOY salmon in Catamaran Brook declined in a manner consistent with a space-limitation hypothesis (i.e., ideal despotic distribution; Steingrímsson and Grant 1999), when densities were three times higher than observed in our study (mean density in mid-July $=1.97 \mathrm{~m}^{-2}$; Steingrímsson and Grant 1999).

In an ideal free distribution, all habitats occupied by fish will produce individuals of average fitness and, hence, con- 
tribute to the viability of populations. Because juvenile Atlantic salmon tolerate a wide range of conditions (see Nislow et al. 1999; Armstrong et al. 2003), they may provide a relatively broad rearing-habitat niche for habitat managers to target. Whether stream salmonid populations shift between an ideal free and an ideal despotic distribution depending on population density or habitat type (Bult et al. 1999) deserves further study.

\section{Acknowledgements}

We thank Rick Cunjak for facilitating our research at Catamaran Brook, Marco Rodríguez for helpful comments regarding data analysis, Keith Nislow, Daniel Boisclair, and two anonymous referees for commenting on the manuscript, and Ivan Benwell, Peter Hardie, István Imre, and Todd Matchim for help with electrofishing. This study was funded by a Research Grant from the Natural Sciences and Engineering Research Council of Canada to J.W.A.G., a Teaching Assistantship from the Department of Biology to I.G., and a Concordia University Graduate Fellowship and an International Fee Remission to S.Ó.S. This paper is Contribution No. 72 of the Catamaran Brook Habitat Research Project.

\section{References}

Armstrong, J.D., Holm, C.F., and Gilvear, D.J. 2002. Holding station against the flow: a reply to Ibbotson \& Dunbar. J. Fish Biol. 61: $308-312$.

Armstrong, J.D., Kemp, P.S., Kennedy, G.J.A., Ladle, M., and Milner, N.J. 2003. Habitat requirements of Atlantic salmon and brown trout in rivers and streams. Fish. Res. 62: 143-170.

Breau, C. 2003. Individual variability in activity patterns of juvenile Atlantic salmon (Salmo salar). M.Sc. thesis, Concordia University, Montréal, Qué.

Bremset, G., and Berg, O.K. 1999. Three-dimensional microhabitat use by young pool-dwelling Atlantic salmon and brown trout. Anim. Behav. 58: 1047-1059.

Bult, T.P., Riley, S.C., Haedrich, R.L., Gibson, R.J., and Heggenes, J. 1999. Density-dependent habitat selection by juvenile Atlantic salmon (Salmo salar) in experimental riverine habitats. Can. J. Fish. Aquat. Sci. 56: 1298-1306.

Cunjak, R.A., Caissie, D., and El-Jabi, N. 1990. The Catamaran Brook habitat research project: description and general design of study. Can. Tech. Rep. Fish. Aquat. Sci. No. 1751.

Cunjak, R.A., Caissie, D., El-Jabi, N., Hardie, P., Conlon, J.H., Pollock, T.L., Giberson, D.J., and Komadina-Douthwright, S. 1993. The Catamaran Brook (New Brunswick) Habitat Research Project: biological, physical and chemical conditions (19901992). Can. Tech. Rep. Fish. Aquat. Sci. No. 1914.

deGraaf, D.A., and Bain, L.H. 1986. Habitat use by and preference of juvenile Atlantic salmon in two Newfoundland Rivers. Trans. Am. Fish. Soc. 115: 671-681.

Dewey, M.R., and Zigler, S.J. 1996. An evaluation of fluorescent elastomer for marking bluegills in experimental studies. Prog. Fish-Cult. 58: 219-220.

Dodson, J.J., Gibson, R.J., Cunjak, R.A., Friedland, K.D., Garcia de Leaniz, C., Gross, M.R., Newbury, R., Nielsen, J.L., Power, M.E., and Roy, S. 1998. Elements in the development of conservation plans for Atlantic salmon (Salmo salar). Can. J. Fish. Aquat. Sci. 55(Suppl. 1): 312-323.
Fretwell, S.D., and Lucas, H.L. 1970. On territorial behaviour and other factors influencing habitat distribution in birds. Acta Biotheor. 19: 16-36.

Gibson, R.J., Stansbury, D.E., Whalen, R.R., and Hillier, K.G. 1993. Relative habitat use, and inter-specific and intra-specific competition of brook trout (Salvelinus fontinalis) and juvenile Atlantic salmon (Salmo salar) in some Newfoundland Rivers. In Production of juvenile Atlantic salmon (Salmo salar) in natural waters. Edited by R.J. Gibson and R.E. Cutting. Can. Spec. Publ. Fish. Aquat. Sci. No. 118. pp. 53-69.

Girard, I. 2002. Foraging and growth in relation to habitat use of young-of-the-year Atlantic salmon (Salmo salar). M.Sc. thesis, Concordia University, Montréal, Qué.

Grant, J.W.A., and Kramer, D.L. 1990. Territory size as a predictor of the upper limit to population density of juvenile salmonids in streams. Can. J. Fish. Aquat. Sci. 47: 1724-1737.

Grant, J.W.A., and Noakes, L.G. 1988. Aggressiveness and foraging mode of young-of-the-year brook trout, Salvelinus fontinalis. (Pisces, Salmonidae). Behav. Ecol. Sociobiol. 22: 435-445.

Guay, J.C., Boisclair, D., Rioux, D., Leclerc, M., Lapointe, M., and Legendre, P. 2000. Development and validation of numerical habitat models for juveniles of Atlantic salmon (Salmo salar). Can. J. Fish. Aquat. Sci. 57: 2065-2075.

Heggenes, J., and Saltveit, S.J. 1990. Seasonal and spatial microhabitat selection and segregation in young Atlantic salmon, Salmo salar L., and brown trout, Salmo trutta L., in a Norwegian River. J. Fish Biol. 36: 707-720.

Hill, J., and Grossman, G.D. 1993. An energetic model of microhabitat use for rainbow trout and rosyside dace. Ecology, 74: 685-698.

Holm, C.F., Armstrong, J.D., and Gilvear, D.J. 2001. Investigating a major assumption of predictive instream habitat models: is water velocity preference of juvenile Atlantic salmon independent of discharge? J. Fish Biol. 59: 1653-1666.

Hughes, N.F., and Dill, L.M. 1990. Position choice by drift-feeding salmonids: model and test for Arctic grayling (Thymallus arcticus) in subarctic mountain streams, interior Alaska. Can. J. Fish. Aquat. Sci. 47: 2039-2048.

Hutchings, J.A., and Jones, M.E.B. 1998. Life history variation and growth rate thresholds for maturity in Atlantic salmon, Salmo salar. Can. J. Fish. Aquat. Sci. 55(Suppl. 1): 22-47.

Imre, I. 2003. Territoriality and population regulation in juvenile salmonids. Ph.D. thesis, Concordia University, Montréal, Qué.

Keeley, E.R., and Grant, J.W.A. 1995. Allometric and environmental correlates of territory size in juvenile Atlantic salmon (Salmo salar). Can. J. Fish. Aquat. Sci. 52: 186-196.

Keeley, E.R., and Grant, J.W.A. 1997. Allometry of diet selectivity in juvenile Atlantic salmon (Salmo salar). Can. J. Fish. Aquat. Sci. 54: 1894-1902.

Keene, J.L., Noakes, D.L.G., Moccia, R.D., and Soto, C.G. 1998. The efficacy of clove oil as an anaesthetic for rainbow trout, Oncorhynchus mykiss (Walbaum). Aquat. Res. 29: 89-101.

Kramer, D.L., Rangeley, R.W., and Chapman, L.J. 1997. Habitat selection: patterns of spatial distribution from behavioural decisions. In Behavioural ecology of teleost fishes. Edited by J.-G.J. Godin. Oxford University Press, Oxford. pp. 37-80.

Metcalfe, N.B., Fraser, N.H.C., and Burns, M.D. 1999. Food availability and the nocturnal vs. diurnal foraging trade-off in juvenile salmon. J. Anim. Ecol. 68: 371-381.

Morantz, D.L., Sweeney, R.K., Shirvell, C.S., and Longard, D.A. 1987. Selection of microhabitat in summer by juvenile Atlantic salmon (Salmo salar). Can. J. Fish. Aquat. Sci. 44: 120-129. 
Nislow, K.H., Folt, C., and Parrish, D.L. 1999. Favorable foraging locations for young Atlantic salmon: application to habitat and population restoration. Ecol. Appl. 9: 1085-1099.

Parrish, D.L., Behnke, R.J., Gepphard, S.R., McCormick, S.D., and Reeves, G.H. 1998. Why aren't there more Atlantic salmon (Salmo salar)? Can. J. Fish. Aquat. Sci. 55(Suppl. 1): 281-287.

Partridge, L. 1978. Habitat selection. In Behavioural ecology, an evolutionary approach. Edited by J.R. Krebs and N.B. Davies. Blackwell, Oxford. pp. 351-376.

Pert, E.J., and Erman, D.C. 1994. Habitat use by adult rainbow trout under moderate artificial fluctuations in flow. Trans. Am. Fish. Soc. 123: 913-923.

Randall, R.G. 1982. Emergence, population densities, and growth of salmon and trout fry in two New Brunswick streams. Can. J. Zool. 60: 2239-2244.

Rimmer, D.M., Paim, U., and Saunders, R.L. 1984. Changes in the selection of microhabitat by juvenile Atlantic salmon (Salmo salar) at the summer-autumn transition in a small river. Can. J. Fish. Aquat. Sci. 41: 469-475.

Rosenfeld, J.S., and Boss, S. 2001. Fitness consequences of habitat use for juvenile cutthroat trout: energetic costs and benefits in pools and riffles. Can. J. Fish. Aquat. Sci. 58: 585-593.

Scruton, D.A., and Gibson, R.J. 1993. The development of habitat suitability curves for juvenile Atlantic salmon (Salmo salar) in riverine habitat in insular Newfoundland, Canada. Can. Spec. Publ. Fish. Aquat. Sci. No. 118. pp. 149-161.

Sokal, R.R., and Rohlf, F.J. 1995. Biometry. 3rd ed. W.H. Freeman \& Co., New York.

Stalnaker, C.B., and Arnette, J.L. (Editors). 1976. Methodologies for the determination of stream resource flow requirements: an assessment. US Fish and Wildlife Service Rep. No. FWS/OBS$76 / 03$.

Steingrímsson, S.Ó., and Grant, J.W.A. 1999. Allometry of territory size and metabolic rate as predictors of self-thinning in young-of-the-year Atlantic salmon. J. Anim. Ecol. 68: 17-26.

Steingrímsson, S.Ó., and Grant, J.W.A. 2003. Patterns and correlates of movement and site fidelity in individually tagged youngof-the-year Atlantic salmon (Salmo salar). Can. J. Fish. Aquat. Sci. 60: 193-202.

Symons, P.E.K., and Heland, M. 1978. Stream habitats and behavioural interactions of underyearling and yearling Atlantic salmon (Salmo salar). J. Fish. Res. Board Can. 35: 175-183.

Walters, C.J., and Juanes, F. 1993. Recruitment limitation as a consequence of natural selection for use of restricted feeding habitats and predation risk-taking by juvenile fishes. Can. J. Fish. Aquat. Sci. 50: 2058-2070. 